\title{
PENGARUH MUTUAL COUPLING PADA BEAMFORMING ANTENA ARRAY
}

\author{
Naufal Widya Gaspura ${ }^{1}$, Dharu Arseno ${ }^{2}$, Alloysius Adya Pramudita ${ }^{3}$ \\ 1, 2, ${ }^{3}$ Prodi S1 Teknik Telekomunikasi, Fakultas Teknik Elektro, Universitas Telkom \\ Indonesia, 40257 \\ 1naufalwidya@student.telkomuniversity.ac.id, \\ 2darseno@telkomuniversity.ac.id, ${ }^{3}$ pramuditaadya@telkomuniversity.ac.id
}

\begin{abstract}
Abstrak
Dalam antena array terdapat efek mutual coupling. Mutual coupling menimbulkan penurunan karakteristik parameter antena. Pada penelitian ini dilakukan analisis pengaruh mutual coupling terhadap hasil beamforming. Dalam penelitian ini, disimpulkan efek dari mutual coupling bergantung jauh-dekatnya jarak antar elemen antena. Dalam simulasi untuk beam mengarah ke 60 derajat, pada jarak $\frac{1}{4}$ lambda hasil beam bergeser sebanyak 70\%. Jarak $\frac{1}{2}$ lambda, beam bergeser sebanyak $25 \%$ ke 45 derajat. Jarak lambda, beam mendekati arah hasil yang diinginkan, tepatnya 64 derajat, di jarak lambda terdapat efek grating lobe. Hasil akhir didapatkan mutual coupling berpengaruh terhadap arah beam yang mengakibatkan pola radiasi antena berubah.
\end{abstract}

Kata Kunci: Antena, Array, Beam forming, Mutual Coupling.

\section{Abstract}

In the antenna array there is a mutual coupling effect. Mutual coupling causes a decrease in the characteristics of the antenna parameters. In this study, an analysis of the effect of mutual coupling on beamforming results was carried out. In this study, it was concluded that the effect of mutual coupling depends on the distance between the antenna elements. In the simulation for the beam pointing to 60 degrees, at a distance of lambda the resulting beam is shifted by $70 \%$. Distance of $\frac{1}{2}$ lambda, beam shifted $25 \%$ to 45 degrees. At $\frac{3}{4}$ lambda distance, the beam is close to the desired result direction, 64 degrees to be precise, at the lambda distance there is a grating lobe effect. In the end, it was found that mutual coupling affects the beam direction which causes the antenna radiation pattern to change.

Key Words: Antenna, Array, Beam forming, Mutual Coupling.

\section{PENDAHULUAN}

Beberapa tahun belakangan ini semua menginginkan akses data yang lebih cepat dan reliable, maka dari itu $5 \mathrm{G}$ hadir untuk menjawab tantangan tersebut. Untuk menjawab tantangan itu, maka diperlukanlah antena sebagai bagian dari teknologi tersebut. Antena merupakan sebuah alat elektronik yang bertujuan untuk mentransmisikan dan menerima gelombang elektromagnetik [1]. Terdapat berbagai jenis antena yang ada, salah satu jenis antena yang bisa digunakan untuk menjawab tantangan tersebut adalah antena array.

Pada penelitian sebelumnya yang berjudul Analisa Pengaruh Mutual Coupling Terhadap Susunan Dua Antena Mikrostrip Segitiga Sama Sisi Dengan Frekuensi Resonan Yang Berbeda $(1.5 \mathrm{GHz}$ dan 1.7 $\mathrm{GHz}$ ) [2], dikatakan mutual coupling dapat memberi efek yang mengakibatkan penurunan kualitas parameter. Penurunan kualitas parameter dikarenakan adanya interferensi elektromagnetik dari dua antena atau lebih yang jaraknya berdekatan. Efek mutual coupling dapat menyebabkan perubahan parameter antena baik gain, return loss, dan pola radiasi yang diinginkan [3].

Untuk itu pada penelitian kali ini kita akan menganalisa pengaruh mutual coupling pada hasil beam forming. Beam forming sendiri bertujuan untuk mengatur efisiensi kerja dalam penggunaan spektrum dan juga dalam pengiriman data ke pengguna [4]. Hal ini dikarenakan konsep beam forming yang memiliki kegunaan untuk memfokuskan sinyal ke area tertentu yang terdapat pengguna di dalamnya. Hal ini berguna dikarenakan sifat sinyal cellular yang dengan mudah terhalang oleh objek-objek tertentu yang akan 


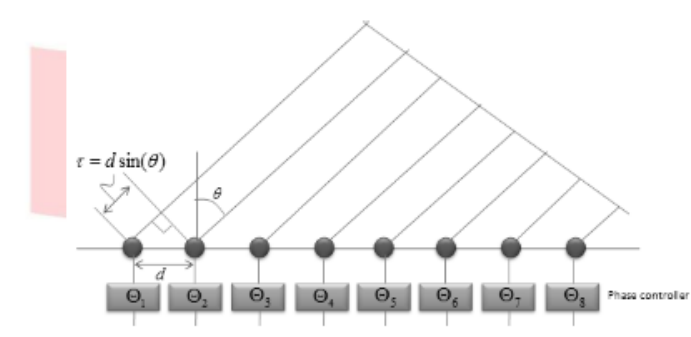

Gambar 1. Konsep Beam forming

mengakibatkan terjadinya pelemahan sinyal akibat jarak yang jauh.

\section{DASAR TEORI}

\subsection{Antena}

Definisi standar persyaratan IEEE untuk antena (IEEE std145-1983) mendefinisikan antena sebagai Sarana untuk memancarkan atau menerima gelombang radio. Antena bertujuan untuk mengirimkan dan menerima gelombang elektomagnetik dalam sistem komunikasi [1].

\subsection{Beam forming}

Beam forming adalah pembentukan pola pancar antena yang dapat disesuaikan dengan kebutuhan user. Beam forming memiliki fungsi untuk dapat memfokuskan sinyal. Beam forming merupakan salah satu jenis manajemen frekuensi radio dimana jalur aksesnya menggunakan beberapa antena untuk mengirimkan pola radiasi yang sama [5]. Konsep beam forming dapat dilihat di Gambar 1. Dengan referensi 1 elemen, maka untuk susunan antena istoropis adalah :

$$
\begin{aligned}
& E_{\text {Total }}=1+e^{j \varphi}+e^{2 j \varphi}+e^{3 j \varphi}+\ldots+e^{j(n-1) j \varphi} \\
& E_{\text {Total }}=\sum_{n=1}^{N} e^{j \varphi(n-1)}
\end{aligned}
$$

Dimana: $n=(1,2,3, . . n), n$ adalah bilangan bulat.

\subsection{Antena Array}

Antena array adalah antena yang terdiri dari beberapa elemen yang saling berhubungan dan diatur dalam struktur yang teratur [6]. Tujuan dari di buatnya sebuah antena array adalah untuk menghasilkan pola radiasi yang memiliki karakteristik tertentu yang diinginkan dengan beberapa elemen menjadi satu. Antenanya sendiri bisa terdiri dari 2 (dua), atau bahkan ribuan (seperti yang di gunakan oleh angkatan udara) [7]. Secara umum, kinerja dari antena ini meningkat sesuai jumlah elemen yang kita buat dalam array. Ilustrasi antena array dapat dilihat pada Gambar 2. Dari Gambar 2, maka nilai keluaran antena dapat

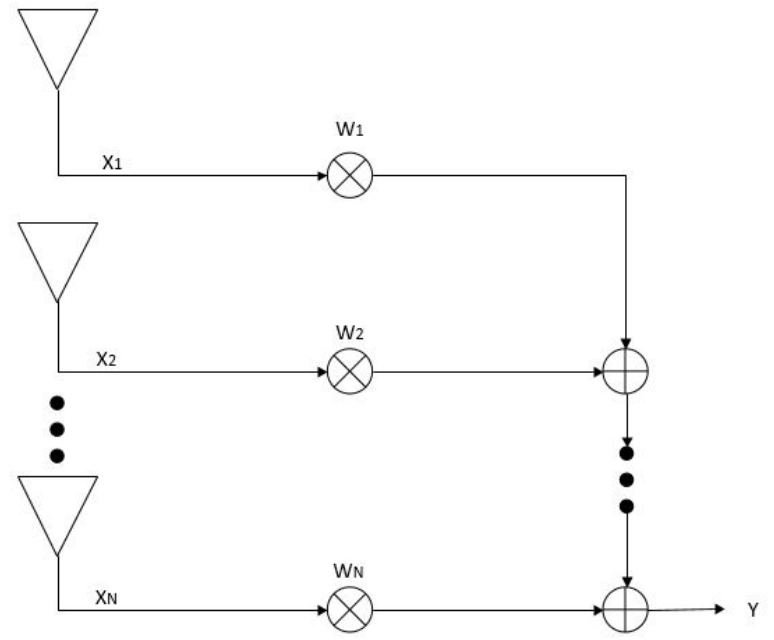

Gambar 2. Ilustrasi Antena Array

dihitung dengan rumus sebagai berikut:

$$
Y=\sum_{n=1}^{N} W_{n} X_{n}
$$

Dimana: $N=(1,2,3, . . n), N$ adalah bilangan bulat. Antena array bertujuan untuk:

1. Meningkatkan keseluruhan gain,

2. Mengarahkan array sehingga menemukan arah paling tepat.

Jika elemen antena memiliki pola radiasi $E_{e}$ lemen, maka pola radiasi akan bernilai sebagai berikut :

$$
E_{\text {Total }}=E_{\text {Elemen }}+E_{\text {Susunan Isotropis }}
$$

\subsection{Mutual Coupling}

Mutual coupling adalah efek yang mengakibatkan perubahan parameter pada antena, seperti impedansi terminal, gain, koefisien pantul dan karakteristik pola radiasi di antena array [6]. Mutual coupling juga dapat dikatakan suatu fenomena yang terjadi pada antena array dimana energi dari satu antena menuju antena lain sehingga mempengaruhi performa antena [8]. Mutual coupling ini dapat merubah besaran arus, fase dan distribusi pada tiap elemen sehingga pola radiasi keseluruhan antena berbeda dibandingkan yang tidak mengalami coupling. Bila jarak antar elemen semakin berdekatan, efek mutual coupling akan semakin meningkat [9].

Besar kecilnya dampak mutual coupling terhadap performansi antena susun bergantung pada:

a. Jenis antena dan parameter desain-nya seperti impedansi elemen dan koefisien refleksi.

b. Letak posisi elemen pada antena susun-nya.

c. Pencatu dari antena susun. 


\section{PEMBAHASAN}

\subsection{Perancangan Dimensi Antena}

Dalam merancang antena array, diperlukan spesifikasi agar antena dapat melihat efek mutual coupling. Untuk memenuhi spesifikasi tersebut, penulis menggunakan antena mikrostrip dengan tipe patch yaitu rectangular. Penulis menggunakan frekuensi $3,5 \mathrm{GHz}$, Substrat FR-4, dan tebal konduktor $0,035 \mathrm{~mm}$.

Perancangan antena array dengan menggunakan 8 (delapan) elemen antena mikrostrip, bertujuan untuk melihat pengaruh dari mutual coupling yang akan terlihat pada beam yang dihasilkan. Dalam Perancangan antena yang dapat melihat hasil beam dan menemukan efek mutual coupling maka, penulis merancang antena menggunakan tools simulasi numerik elektromagnetik. Penulis membuat antena mikrostip dengan desain patch berbentuk rectangular dengan tipe catuan microstripline.

\subsection{Perancangan Rectangular Patch}

Dalam perancangan penulis menggunakan spesifikasi sebagai berikut: Dari spesifikasi di atas,

$\begin{array}{ll}\text { Jumlah Elemen } & : 8 \\ \text { Frekuensi } & : 3,5 \mathrm{GHz} \\ \text { Substrat FR-4 } & : 1,6 \mathrm{~mm} \\ \text { Konstanta Dielektrik } & : 4,3 \\ \text { Tebal Konduktor } & : 0,035\end{array}$

penulis dapat mendapatkan dimensi antena yang akan di rancang. Berikut merupakan hasil perhitungan dimensi sesuai spesifikasi yang dibutuhkan. Parameter tersebut dapat dilihat pada Tabel 1. Dengan

Tabel 1. Parameter Perancangan Antena Mikrostrip 3.5 GHz

\begin{tabular}{|c|c|c|}
\hline keterangan & Nilai & Simbol \\
\hline Tebal Dielektrik & $1,6 \mathrm{~mm}$ & $\mathrm{H}$ \\
\hline Tebal Konduktor & $0,035 \mathrm{~mm}$ & $\mathrm{~T}$ \\
\hline Panjang Feed & $11,86 \mathrm{~mm}$ & LF \\
\hline Lebar Feed & $3,2637 \mathrm{~mm}$ & WF \\
\hline Panjang Patch & $20,2172 \mathrm{~mm}$ & LP \\
\hline Lebar Patch & $26,33 \mathrm{~mm}$ & WP \\
\hline Panjang Groundplan & 29,8172 & LG \\
\hline Lebar Groundplan & 35,93 & WG \\
\hline
\end{tabular}

memasukkan hasil perhitungan parameter di Tabel 1 , penulis melakukan perancangan dengan bantuan tools simulasi numerik elektromagnetik dan menghasilkan desain antena dengan patch rectangular seperti di Gambar 3.

Dari Gambar 3, penulis melakukan pengolahan dari desain antena tersebut dan membuat elemen

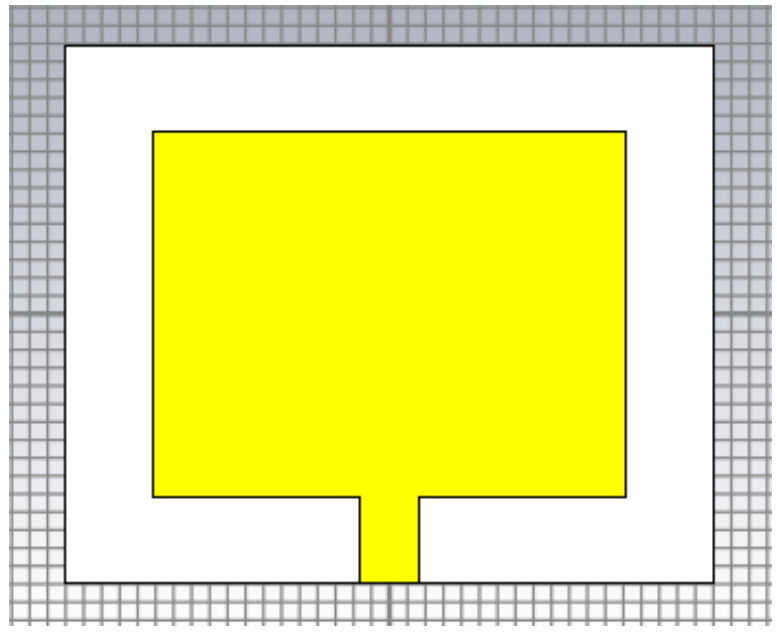

\section{Gambar 3. Desain Antena Mikrostrip}

berjumlah 8 (delapan) sesuai dengan spesifikasi yang diinginkan. Hal ini diperuntukkan sebagai antena yang dapat melakukan simulasi untuk melihat efek mutual coupling. Maka penulis membuat desain dengan antena yang sesuai spesifikasi seperti pada Gambar 4 .

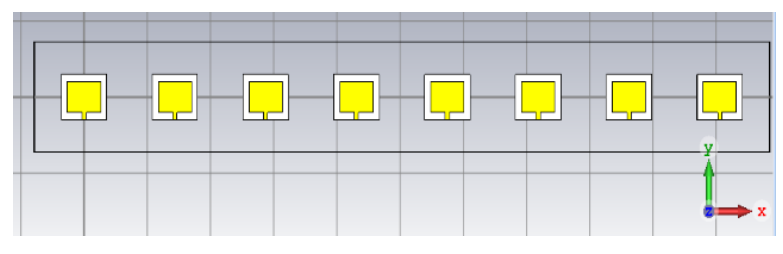

Gambar 4. Desain Antena Array 8 Elemen

\section{HASIL DAN ANALISIS}

\subsection{Hasil dan Analisis Simulasi Antena}

Dari hasil simulasi yang dilakukan menggunakan bantuan MATLAB dan tools simulasi numerik elektromagnetik. Untuk melihat efek dari mutual coupling terhadap beam forming, penulis melakukan penyetelan untuk arah beam di 60 derajat. Penulis melakukan pengecekan hasil beam forming pada antena 1 (satu) elemen yang belum di coupling sebagai bahan validasi. Hasil dari antena yang belum memliki coupling dapat dilihat pada Gambar 5. Penulis melakukan beberapa simulasi dengan jarak yang berbeda-beda, diantara lain adalah sebagai berikut:

1. Jarak antar elemen antena lambda. Pada jarak ini penulis melakukan percobaan dengan menggunakan jarak antar elemen antena, yaitu $\frac{1}{4}$ lambda. Penulis melakukan pengecekan untuk hasil beam forming pada antena isotropis dan hasilnya akan terlihat seperti pada Gambar 6.

Untuk melakukan simulasi pada tools simulasi numerik elektromagnetik, penulis menggunakan 


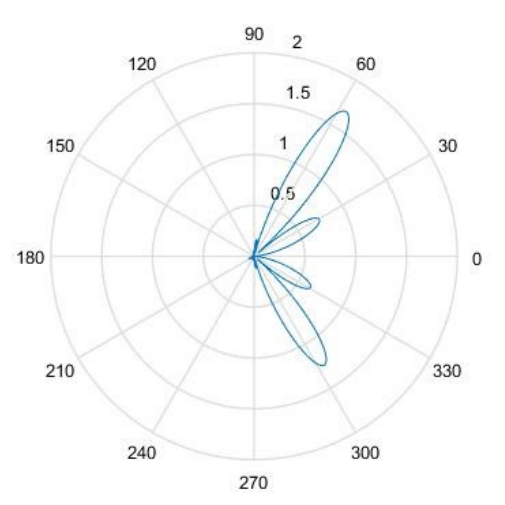

Gambar 5. Hasil Beam forming Antena 1 Elemen Tanpa Coupling

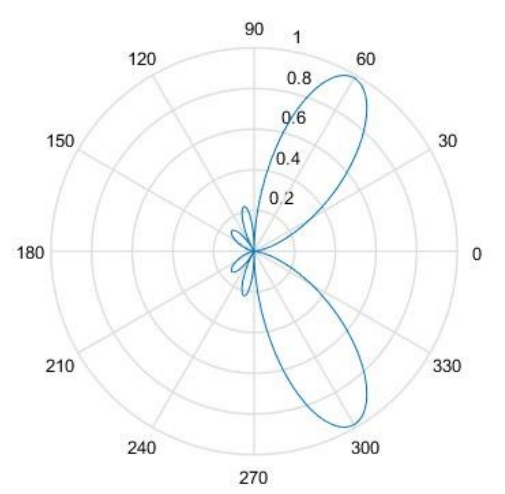

Gambar 6. Hasil Beam forming Antena Isotropis Jarak $\frac{1}{4}$ Lambda

nilai amplitudo dan phase shifter yang didapatkan dari hasil simulasi di MATLAB. Nilai amplitudo dan phase shifter yang diperoleh digunakan sebagai nilai bobot untuk antena dengan jarak $\frac{1}{4}$ lambda yang diberi kopling. Nilai Amplitudo dan phase shifter dapat dilihat di Tabel 2.

Dalam hal ini, penulis menggunakan data di Tabel 2 sebagai nilai bobot yang akan digunakan untuk melakukan simulasi pada tools simulasi numerik elektromagnetik. Hasil dari efek mutual coupling pada beam forming akan terlihat seperti pada Gambar 7. Pada gambar tersebut menandakan efek mutual coupling yang sangat berpengaruh pada beam yang dihasilkan. Adanya pergeseran yang cukup signifikan (sekitar 70\%) dari nilai beam yang di inginkan (60 derajat).

Untuk melihat nilai dari besar mutual coupling
Tabel 2. Nilai Amplitudo dan Phase Shifter Jarak $\frac{1}{4}$ Lambda

\begin{tabular}{|c|c|c|}
\hline $\begin{array}{c}\text { Elemen } \\
\text { ke- }\end{array}$ & Amplitudo & $\begin{array}{c}\text { Phase Shifter } \\
\text { (dalam derajat) }\end{array}$ \\
\hline 1 & 0,1230 & 0 \\
\hline 2 & 0,1230 & -45 \\
\hline 3 & 0,1230 & -90 \\
\hline 4 & 0,1230 & -135 \\
\hline 5 & 0,1230 & 180 \\
\hline 6 & 0,1230 & 135 \\
\hline 7 & 0,1230 & 90 \\
\hline 8 & 0,1230 & 45 \\
\hline
\end{tabular}

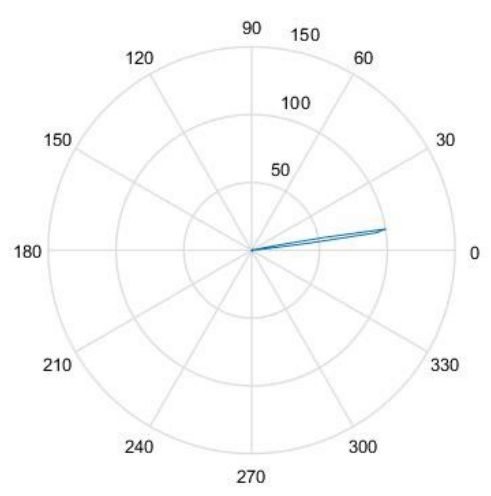

Gambar 7. Hasil Beam forming Antena 8 Elemen Jarak $\frac{1}{4}$ Lambda

dapat menggunakan S-Parameter. Pada kondisi jarak $\frac{1}{4}$ lambda garis-garis parameter berdekatan menandakan nilai mutual coupling besar. Bisa dilihat di Gambar 8.

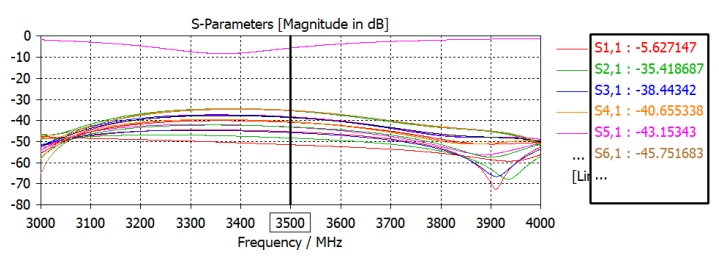

Gambar 8. Nilai S-Parameter Antena 8 Elemen Jarak $\frac{1}{4}$ Lambda

2. Jarak antar elemen antena $\frac{1}{2}$ lambda.

Penulis melakukan percobaan dengan menggunakan jarak antar elemen antena, yaitu $\frac{1}{2}$ lambda. Penulis melakukan pengecekan untuk hasil beam forming pada antena isotropis di jarak tersebut hasilnya terlihat pada Gambar 9. Seperti pada percobaan pertama, penulis juga 


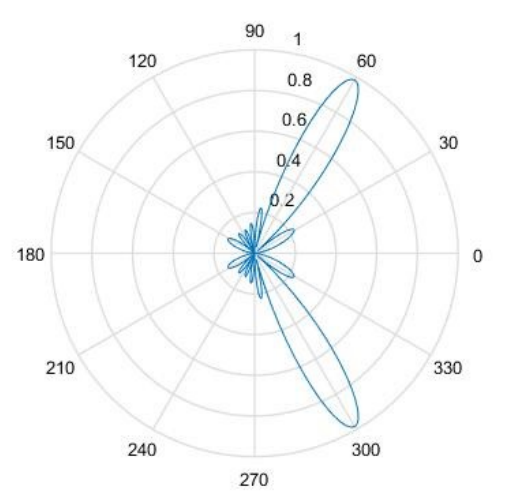

\section{Gambar 9. Hasil Beam forming Antena Isotropis Jarak $\frac{1}{2}$ Lambda}

menggunakan nilai amplitudo dan phase shifter yang akan diperlukan sebagai nilai bobot di antena 8 elemen untuk melihat efek dari nilai mutual coupling. Nilai Amplitudo dan phase shifter dapat dilihat di Tabel 3. Dalam hal ini,

Tabel 3. Nilai Amplitudo dan Phase Shifter Jarak $\frac{1}{2}$ Lambda

\begin{tabular}{|c|c|c|}
\hline $\begin{array}{c}\text { Elemen } \\
\text { ke- }\end{array}$ & Amplitudo & $\begin{array}{c}\text { Phase Shifter } \\
\text { (dalam derajat) }\end{array}$ \\
\hline 1 & 0,1230 & 0 \\
\hline 2 & 0,1230 & -90 \\
\hline 3 & 0,1230 & 180 \\
\hline 4 & 0,1230 & 90 \\
\hline 5 & 0,1230 & 0 \\
\hline 6 & 0,1230 & -90 \\
\hline 7 & 0,1230 & 180 \\
\hline 8 & 0,1230 & 90 \\
\hline
\end{tabular}

penulis menggunakan data di Tabel 3 sebagai nilai bobot yang akan digunakan untuk melakukan simulasi pada tools simulasi numerik elektromagnetik. Hasil dari efek mutual coupling pada beamforming terlihat pada Gambar 10. Pada kondisi jarak $\frac{1}{2}$ lambda garis-garis pada S-Parameter menandakan nilai mutual coupling. Bisa dilihat pada Gambar 11.

3.1 Jarak antar elemen antena $\frac{3}{4}$ lambda

Penulis melakukan percobaan dengan menggunakan jarak antar elemen antena, yaitu $\frac{3}{4}$ lambda. Penulis melakukan pengecekan hasil beam forming pada antena isotropis dengan jarak tersebut, hasilnya terlihat pada Gambar 12.

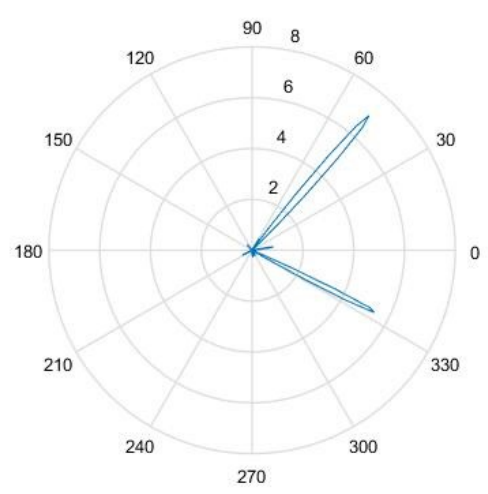

Gambar 10. Hasil Beam forming Antena 8 Elemen Jarak $\frac{1}{2}$ Lambda

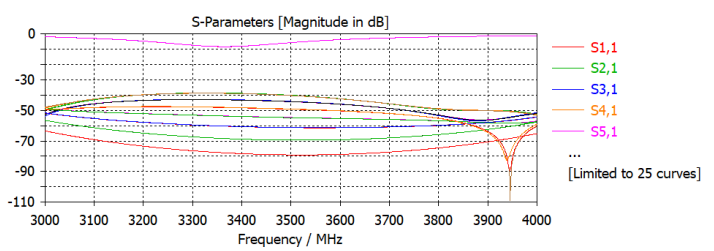

Gambar 11. Nilai S-Parameter Antena 8 Elemen Jarak $\frac{1}{2}$ Lambda

Pada percobaan ke-tiga ini, penulis mendapatkan nilai amplitudo dan phase shifter yang berbeda yang diperlukan sebagai nilai bobot pada tools simulasi numerik elektromagnetik. Nilai Amplitudo dan phase shifter dapat dilihat di Tabel 4.

Tabel 4. Nilai Amplitudo dan Phase Shifter Jarak $\frac{3}{4}$ Lambda

\begin{tabular}{|c|c|c|}
\hline $\begin{array}{c}\text { Elemen } \\
\text { ke- }\end{array}$ & Amplitudo & $\begin{array}{c}\text { Phase Shifter } \\
\text { (dalam derajat) }\end{array}$ \\
\hline 1 & 0,1230 & 0 \\
\hline 2 & 0,1230 & -135 \\
\hline 3 & 0,1230 & 90 \\
\hline 4 & 0,1230 & -45 \\
\hline 5 & 0,1230 & 180 \\
\hline 6 & 0,1230 & 45 \\
\hline 7 & 0,1230 & -90 \\
\hline 8 & 0,1230 & 135 \\
\hline
\end{tabular}

Nilai pada Tabel 4. digunakan untuk nilai bobot pada tools simulasi numerik elektromagnetik. Pada percobaan ini, arah beam yang didapatkan setelah diberikan efek mutual coupling mendekati arah yang penulis setel pada awal 


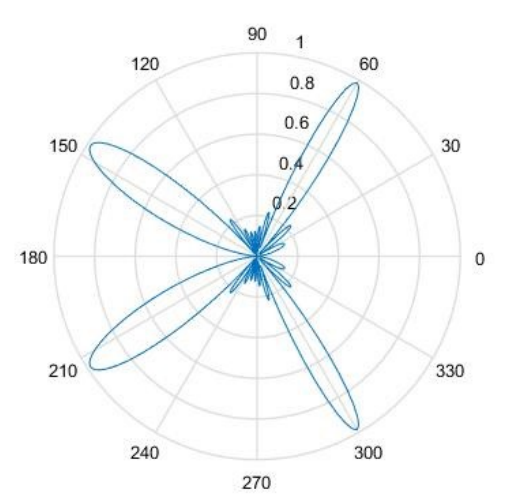

Gambar 12. Hasil Beam forming Antena Isotropis Jarak $\frac{3}{4}$ Lambda

percobaan (60 derajat). Hasilnya dilihat pada Gambar 13.

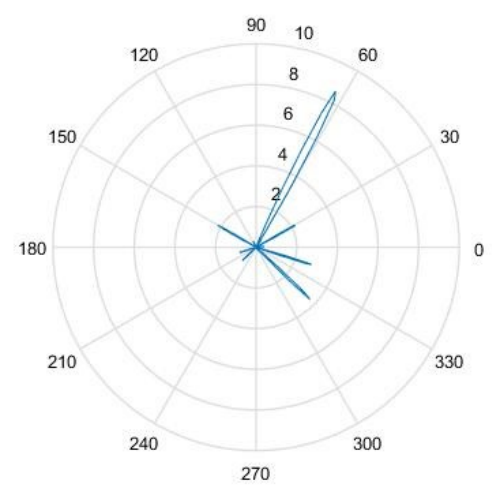

Gambar 13. Hasil Beam forming Antena 8 Elemen Jarak $\frac{3}{4}$ Lambda

Pada Gambar 13 terlihat bahwa arah beam hampir mengarah pada 60 derajat, hal demikian dibuktikan juga dari nilai S-Parameter seperti di Gambar 14. Bisa dilihat pada nilai S-Parameter, garis-garis parameter berjauhan menandakan efek dari mutual coupling berkurang diakibatkan oleh jarak yang diubah menjadi lebih jauh.

4. Jarak antar elemen antena lambda Pada percobaan terakhir ini, penulis melakukan pengecekan dengan jarak lambda. Sama seperti pada percobaan sebelumnya penulis melakukan pengecekan pada hasil beam di antena isotropis dengan jarak tersebut, dan hasilnya dapat dilihat pada Gambar 15. Pada percobaan terakhir, penulis juga melakukan pengecekan nilai

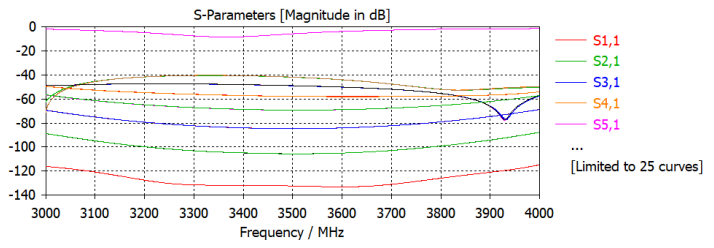

Gambar 14. Nilai S-Parameter Antena 8 Elemen Jarak $\frac{3}{4}$ Lambda

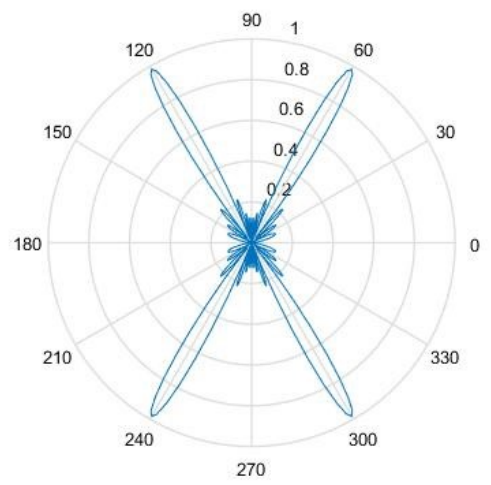

Gambar 15. Hasil Beam forming Antena Isotropis Jarak Lambda

amplitudo dan phase shifter yang dihasilkan dari jarak lambda. Pada perubahan jarak otomatis juga akan membuat perubahan pada nilai phase shifter, seperti yang dapat dilihat pada Tabel 5 .

Tabel 5. Nilai Amplitudo dan Phase Shifter Untuk Lambda

\begin{tabular}{|c|c|c|}
\hline $\begin{array}{c}\text { Elemen } \\
\text { ke- }\end{array}$ & Amplitudo & $\begin{array}{c}\text { Phase Shifter } \\
\text { (dalam derajat) }\end{array}$ \\
\hline 1 & 0,1230 & 0 \\
\hline 2 & 0,1230 & 180 \\
\hline 3 & 0,1230 & 0 \\
\hline 4 & 0,1230 & 180 \\
\hline 5 & 0,1230 & 0 \\
\hline 6 & 0,1230 & 180 \\
\hline 7 & 0,1230 & 0 \\
\hline 8 & 0,1230 & 180 \\
\hline
\end{tabular}

Seperti pada percobaan sebelumnya, nilai pada Tabel 5 akan digunakan untuk mengisi nilai bobot, yang berguna untuk 8 elemen antena dengan jarak lambda pada tools simulasi numerik elektromagnetik. Pada saat di jarak lambda hasil beam-nya dapat dilihat pada Gambar 16 dan nilai dari S-Parameter dapat 
dilihat pada Gambar 17.

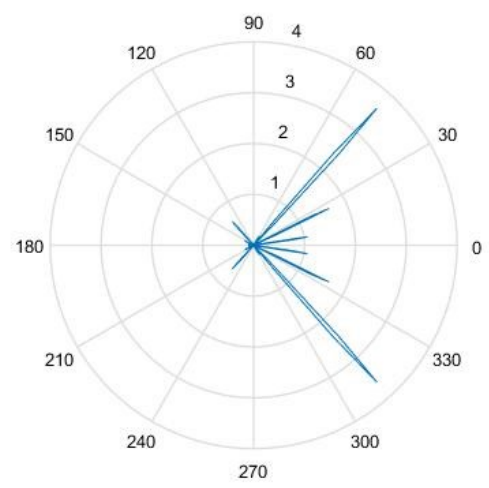

Gambar 16. Hasil Beam forming Antena 8 Elemen Jarak Lambda

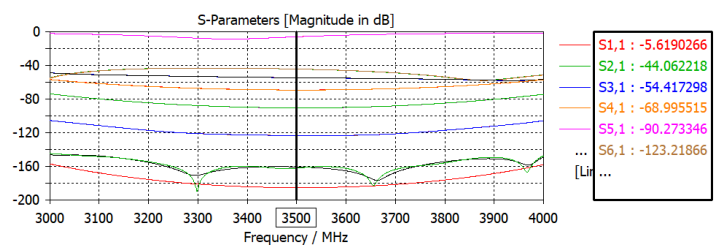

\section{Gambar 17. Nilai S-Parameter Antena 8 Elemen Jarak Lambda}

Dilihat pada Gambar 12 dan 15 dalam pengaturan di antena isotropis yang di arah 60 derajat terdapat efek yang dinamakan grating lobe. Grating Lobe merupakan side lobe yang membesar dan menyerupai main lobe, hal ini disebabkan oleh efek dimana perubahan jarak antar elemen antena dibuat menjadi jauh [10].

\section{KESIMPULAN}

Berdasarkan hasil yang diperoleh dari percobaan simulasi efek mutual coupling terhadap hasil beam forming di antena array dengan elemen berjumlah 8 (delapan), maka penulis mendapatkan kesimpulan sebagai berikut:

1. Efek mutual coupling mengakibatkan pergeseran ataupun perubahan arah dari beam antena yang sudah kita atur pattern-nya. Pergeseran arah beam bergantung kepada nilai dari efek mutual coupling itu sendiri.

2. Semakin jauh jarak antar elemen antena, maka semakin kecil juga nilai dari efek mutual coupling. Begitu juga sebaliknya, semakin dekat jarak antar elemen antena, maka nilai dari mutual coupling akan semakin besar.
3. Jumlah elemen antena array berpengaruh terhadap hasil beam forming. Semakin banyak jumlah elemen antena maka akan semakin fokus beam yang dihasilkan.

4. S-Parameter digunakan untuk melihat nilai dari efek coupling, baik antara antena itu sendiri maupun antar antena yang lain.

5. Jarak antar elemen antena akan berpengaruh terhadap nilai phase shifter.

\section{Daftar Pustaka}

[1] W. L. Stutzman and G. A. Thiele, Antenna theory and design. John Wiley \& Sons, 2012.

[2] R. G. R. Tobing, "Analisa pengaruh mutual coupling terhadap susunan dua antena mikrostrip segitiga samasisi dengan frekuensi resonan yang berbeda (1, $5 \mathrm{ghz}$ dan 1, $7 \mathrm{ghz})$," Bandung: Institut Teknologi Telkom, 2012.

[3] M. A. Ali and P. Wahid, "Analysis of mutual coupling effect in adaptive array antennas," in IEEE Antennas and Propagation Society International Symposium (IEEE Cat. No. 02CH37313), vol. 1. IEEE, 2002, pp. 102-105.

[4] A. Nordrum, K. Clark, and I. Staff, "5g bytes: beamforming explained," IEEE spectrum staff,(Jul 2017), 2017.

[5] P. Chaipanya, P. Uthansakul, and M. Uthansakul, "Reduction of inter-cell interference using vertical beamforming scheme for fractional frequency reuse technique," in Asia-Pacific Microwave Conference 2011. IEEE, 2011, pp. 1614-1617.

[6] C. A. Balanis, Antenna theory: analysis and design. John wiley \& sons, 2016.

[7] J. D. Kraus, Antennas, 3rd ed. McGraw-Hill, 2001.

[8] H. Singh, H. Sneha, and R. Jha, "Mutual coupling in phased arrays: A review," International Journal of Antennas and Propagation, vol. 2013, 2013.

[9] H. Werfelli, K. Tayari, M. Chaoui, M. Lahiani, and H. Ghariani, "Design of rectangular microstrip patch antenna," in 2016 2nd International Conference on Advanced Technologies for Signal and Image Processing (ATSIP). IEEE, 2016, pp. 798-803.

[10] F. J. Pompei and S.-C. Wooh, "Phased array element shapes for suppressing grating lobes," The Journal of the Acoustical Society of America, vol. 111, no. 5, pp. 2040-2048, 2002. 